\title{
Perillyl Alcohol Inhibits Breast Cell Migration without Affecting Cell Adhesion
}

\author{
Johanna E. Wagner, ${ }^{1}$ Janice L. Huff, ${ }^{1}$ William L. Rust,${ }^{1}$ Karl Kingsley, ${ }^{1}$ and George E. Plopper ${ }^{2 *}$ \\ ${ }^{1}$ UNLV Cancer Institute and Department of Biological Sciences, University of Nevada, Las Vegas, NV 89154, USA \\ ${ }^{2}$ Department of Biology, Rensselaer Polytechnic Institute, 110 8th Street, Troy, NY 12180-3590, USA
}

Received 4 June 2002; accepted 20 July 2002

\begin{abstract}
The monoterpene d-limonene exhibits chemotherapeutic and chemopreventive potential in breast cancer patients. D-limonene and its related compounds, perillyl alcohol and perillyl aldehyde, were chosen as candidate drugs for application in a screen for nontoxic inhibitors of cell migration. Using the nontumorigenic human breast cell line MCF-10A, we delineated the toxicity as greatest for the perillyl aldehyde, intermediate for perillyl alcohol, and least for limonene. A noncytotoxic concentration of $0.5 \mathrm{mmol} / \mathrm{L}$ perillyl alcohol inhibited the migration, while the same concentration of limonene failed to do so. Adhesion of the MCF-10A cell line and the human breast cancer cell line MDA-MB 435 to fibronectin was unaffected by $1.5 \mathrm{mmol} / \mathrm{L}$ perillyl alcohol. $0.4 \mathrm{mmol} / \mathrm{L}$ perillyl alcohol inhibited the growth of MDA-MB 435 cells. All migration-inhibiting concentrations of perillyl alcohol for MDA-MB 435 cells proved to be toxic. These results suggest that subtoxic doses of perillyl alcohol may have prophylactic potential in the treatment of breast cancer.
\end{abstract}

\section{INTRODUCTION}

Cancer remains the second leading cause of death in the US, American Cancer Society, http://www.cancer.org. Tumor metastasis is the most deadly characteristic of cancer. Unlike primary tumors that can be surgically removed and treated with adjuvant chemotherapy and/or radiotherapy, metastases are difficult to treat and usually prove fatal [1].

The development of secondary tumors is a sequential process, commonly referred to as a "metastatic cascade," and failure to complete any one step prevents metastasis [1]. During the metastatic cascade, primary tumor cells digest their surrounding extracellular matrix, migrate through interstitial spaces, and enter blood or lymphatic vessels where they are carried to distant organs. Once lodged in the target organs, these cells migrate into the interstitial spaces and continue to grow to develop a secondary tumor, or metastasis [2]. Thus, the migration and invasion of cancer cells provides many potential targets for therapeutic intervention.

Most anticancer drugs target the hyperproliferation of metastatic cells. While many of these drugs are efficacious in treating the beginning stages of cancer, none are curative for metastatic disease. Any delay in the diagnosis also renders many of these drugs ineffective [3]. In addition, antiproliferation compounds cause many adverse side effects, including nausea, vomiting, suppressed immune system, and hair loss. It is, therefore, paramount that alternative therapies be developed to treat a greater scope of the disease with less disturbance to the wellbeing of the patient.

Even though tumor cell migration is a hallmark feature of metastasis, since 1978, fewer than 100 compounds that have some capacity to inhibit tumor cell migration have been reported; however, thousands of compounds have yet to be tested. To address the need for a more comprehensive screen of possible antimigration compounds, we recently, developed an automated high-throughput cytotoxicity/cell migration assay suitable for screening large numbers of samples [4].

During the development of our automated assay, we applied cell proliferation and migration assays to screen drugs, already known to have anticancer effects, for noncytotoxic antimigration properties. This report focuses on the effects of d-limonene and its derivatives. The chemotherapeutic and chemopreventative effects of d-limonene, a monoterpene found in the essential oils of citrus fruits, spices, and herbs, have been studied extensively in spontaneous and chemically induced rodent tumors [5]. Limonene serves as a precursor to other oxygenated monocyclic monoterpenes such as carveol, carvone, menthol, perillyl alcohol (POH), and perillyl aldehyde [6]. Due to success in tumor regression in various rodent cancer models, clinical testing of the cancer chemotherapeutic activity of these compounds is in progress, including Phase I clinical trials of $\mathrm{POH}$ in breast cancer patients $[7,8]$.

D-limonene and its derivatives disrupt isoprenylation of members of the Ras family of $G$ proteins by geranylgeranyl transferases in some instances [9], though the effects of this disruption on downstream cellular behaviors are only now being elucidated. Thus much of the focus far has been on the inhibition of the cell cycle machinery and the induction of apoptosis [10]. The effects of these compounds on migration, especially in breast cells, are unreported to date. 
We report here that $\mathrm{POH}$ inhibits migration of both malignant and nonmalignant human breast cells, and that migration inhibiting doses also prove cytotoxic in malignant cells. These results suggest that subtoxic doses of $\mathrm{POH}$ may act as a preventative treatment for breast cancer.

\section{MATERIALS AND METHODS}

\section{Materials}

MCF-10A and MDA-MB 435 cells were purchased from American Type Culture Collection. Fibronectin, epidermal growth factor, cholera toxin, and insulin were obtained from Calbiochem (La Jolla, Calif). Hydrocortisone was purchased from Sigma-Aldrich Chemicals (St. Louis, Mo). Horse serum was purchased from Irvine Scientific (Santa Ana, Calif). Calcein-AM was purchased from Molecular Probes (Eugene, Ore). Transwell migration plates were purchased from Costar (Cambridge, Mass). Cell culture flasks and 96-well plates were purchased from VWR (Plainfield, NJ). Limonene, $\mathrm{POH}$, and perillyl aldehyde were purchased from Aldrich Chemical Co. (Milwaukee, Wis).

\section{Cell culture}

Cells were grown in $75 \mathrm{~cm}^{2}$ Falcon tissue culture flasks obtained from VWR (Plainfield, NJ). Cells were maintained at $37^{\circ} \mathrm{C}$ and $5 \% \quad \mathrm{CO}_{2}$ in humidified chambers. MCF-10A cells were maintained in AM media-1:1 mixture of Ham's F-12 medium and Dulbecco's Modified Eagle's Medium High Glucose with $2 \mathrm{mmol} / \mathrm{L}$ L-glutamine from Irvine Scientific (Santa Ana, Calif, USA) supplemented with the following: epidermal growth factor $(20 \mathrm{ng} / \mathrm{mL})$, cholera toxin $(100 \mathrm{ng} / \mathrm{mL})$, insulin $(0.01 \mathrm{mg} / \mathrm{mL})$, hydrocortisone ( $500 \mathrm{ng} / \mathrm{mL}$ ), and 5\% horse serum. MDA-MB 435 cells were maintained in RPMI Medium 1640 supplemented with $10 \%$ fetal bovine serum and 1\% L-glutamine $(29.2 \mathrm{mg} / \mathrm{mL})$, penicillin G (10000 units $/ \mathrm{mL})$ and streptomycin sulfate $(10000 \mu \mathrm{g} / \mathrm{mL})$ from Irvine Scientific (Santa Ana, Calif). Cells were routinely passaged using trypsin/EDTA from Irvine Scientific (Santa Ana, Calif).

\section{Proliferation assay}

In 96-well plates, $30 \times 10^{3}$ cells were seeded in the appropriate serum-containing media and incubated for 2 hours at $37^{\circ} \mathrm{C}$ and $5 \% \mathrm{CO}_{2}$ in humidified chambers. Cells were then washed twice with $\mathrm{PBS}$ and grown in migration media (MCF-10A: DMEM and 0.1\% BSA; MDA-MB 435: RPMI 1640 and $0.1 \%$ BSA) with indicated concentrations of limonene, perillyl alcohol, or perillyl aldehyde for 24 hours. Cells were then washed twice with PBS, fixed in $3.7 \%$ formaldehyde for 15 minutes, stained with crystal violet and lysed with $1 \%$ sodium docecyl sulfate (SDS). Absorbance was read at $595 \mathrm{~nm}$ using a plate reader. Growth was measured as compared to a standard curve of cells grown in serum-containing media.

\section{Adhesion assay}

Cell adhesion assays were performed as previously described in Costar 96-well Cell Culture Cluster plates [11].
Tissue culture plates were coated with purified fibronectin $(20 \mu \mathrm{g} / \mathrm{mL}$ in $50 \mathrm{mmol} / \mathrm{L}$ carbonate buffer, $\mathrm{pH} 9.3)$ for 1 hour at room temperature. Wells were then washed with phosphate-buffered saline with $0.2 \%$ Tween-20 (PBST), blocked with 5\% blotto (PBST with 5\% skim milk) for 1 hour at $25^{\circ} \mathrm{C}$. Wells were then washed twice with PBST prior to assay. Cells were seeded at a concentration of $1.0 \times 10^{6}$ per well in cell culture plates with and without migration media (MCF-10A: DMEM and 0.1\% BSA; MDA-MB 435: RPMI 1640 and $0.1 \%$ BSA) and perillyl alcohol and were allowed to attach for 30 minutes at $37^{\circ} \mathrm{C}$ in a humidified incubator containing $5 \% \mathrm{CO}_{2}$. Unbound cells were dislodged by inverting, submerging and rocking the plate in PBS for 15 minutes. Cells were then fixed in $3.7 \%$ formaldehyde, stained with crystal violet, and lysed with 1\% SDS. Absorbance was measured at $595 \mathrm{~nm}$ in a plate reader.

\section{Migration assay}

Cell migration assays were performed as previously described in Costar transwell filter plates [6]. Filters were coated with purified fibronectin at a concentration of $20 \mu \mathrm{g} / \mathrm{mL}$ in carbonate buffer $(50 \mathrm{mmol} / \mathrm{L}, \mathrm{pH} 9.3)$ for 1 hour at room temperature. Filters were then aspirated and blocked in blotto (phosphate-buffered saline with $0.2 \%$ Tween-20 (PBST) and 5\% skim milk) for 1 hour at room temperature. Next, filters were washed in PBST prior to the assay. Thirty minutes prior to starting the assay, cells were preincubated at $37^{\circ} \mathrm{C}$ in migration media and the indicated concentrations of $\mathrm{POH}$. Cells were seeded at a concentration of $1.2 \times 10^{6} /$ well on transwell filters with and without fibronectin in the presence or absence of soluble growth factors (serum-enriched media) and varying concentrations of $\mathrm{POH}$ and allowed to migrate for 18 hours at $37^{\circ} \mathrm{C}$ in $5 \% \mathrm{CO}_{2}$. Thirty minutes before measuring the migration, $5 \mu \mathrm{mol} / \mathrm{L}$ of calcein-AM (Molecular Probes; Eugene, Ore) was added to the migration wells. To quantify the migration, cells were removed from the top of the filter with cotton swabs, washed in phosphate-buffered saline and the fluorescence measured from the bottom of the filter with a plate reader for the incorporation of calcein-AM [7]. Relative fluorescence values for each experimental condition were expressed relative to control untreated samples.

\section{RESULTS AND DISCUSSION}

D-limonene and its derivatives, $\mathrm{POH}$ and perillyl aldehyde, exhibited different degrees of toxicity in a 24-hour growth assay. D-limonene did not inhibit growth of MCF$10 \mathrm{~A}$ cells at concentrations up to $1.0 \mathrm{mmol} / \mathrm{L}$ (Figure 1 ) or greater (not shown), while $0.5 \mathrm{mmol} / \mathrm{L}$ perillyl aldehyde was completely toxic. In contrast, $0.5 \mathrm{mmol} / \mathrm{L} \mathrm{POH}$ was not cytotoxic, but concentrations of $0.75 \mathrm{mmol} / \mathrm{L}$ and $1.0 \mathrm{mmol} / \mathrm{L}$ were cytostatic and cytotoxic, respectively. The relatively high toxicity of perillyl aldehyde may be due to a proportionally high affinity for the enzymes farnesyl transferase (FT) and geranylgeranyl transferase (GGT) as has been shown for perillic acid methyl ester, a minor metabolite of limonene, and $\mathrm{POH}[12]$. These enzymes are involved in post-translational 


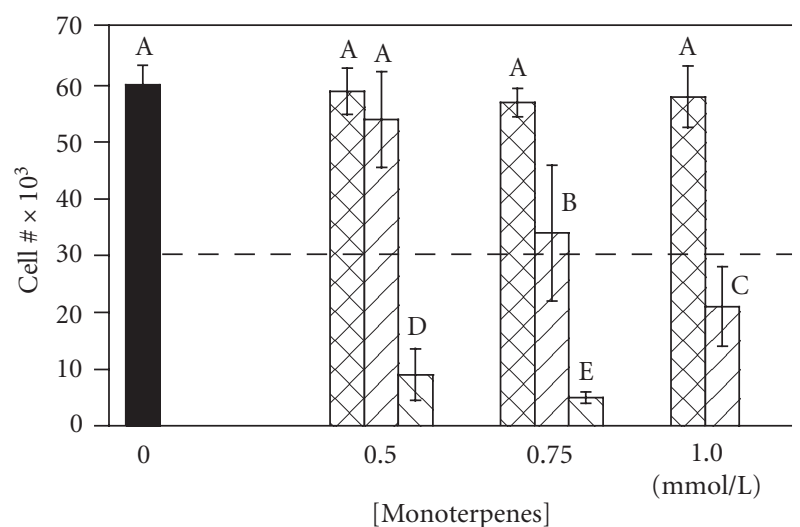

Minimal medium
D-limonene
Perillyl alcohol
Perillaldehyde

FIGURE 1. Monoterpenes exhibit varying degrees of inhibition of breast cell growth. MCF-10A cells were plated at $30 \times 10^{3}$ cells/well (dashed line) in serum-free minimal medium containing the indicated concentrations of monoterpenes, and counted 24 hours later. Bars represent mean \pm standard deviation $(n=10)$. A student-Numan-Keuls test identified five groups (letters A-E; $P \leq .05$ ) which were statistically different from one another (ANOVA F: $[9,98]=121.63, P<.0001$ ).

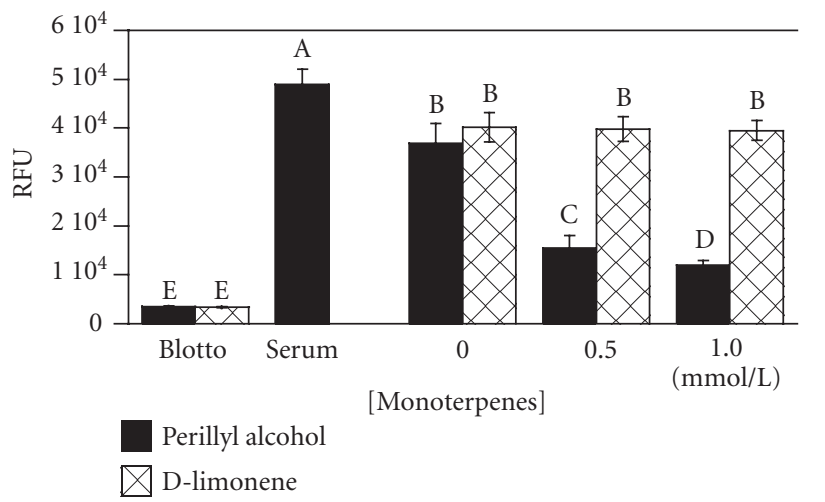

Figure 2. Perillyl alcohol, but not d-limonene, inhibits breast cell migration. MCF-10A cells were allowed to migrate towards the bottom side of an 8 - $\mu \mathrm{m}$ pore filter coated with fibronectin for 18 hours in serum-free minimal medium containing the indicated concentrations of monoterpenes, or serum as a control. Migration towards nonfat dried milk (blotto) served as a negative control for random migration. Migration was quantitated by fluorescently labeling cells on the bottom of the filters and reading the fluorescence with a plate reader. Results expressed as mean of Relative Fluorescence Units, \pm standard deviation $(n=3)$. A student-Numan-Keuls test identified five groups (letters A-E; $P \leq .05$ ) which were statistically different from one another (ANOVA F: $[7,23]=231.76, P<.0001$ ).

modification of small G-proteins that are involved in a myriad of cell activities such as growth and migration. Inhibition of FT and GGT is suspected to be the basis of the antitumor effects of $\mathrm{POH}$ and limonene [12]. However, in accord with our data, an equal concentration of limonene is

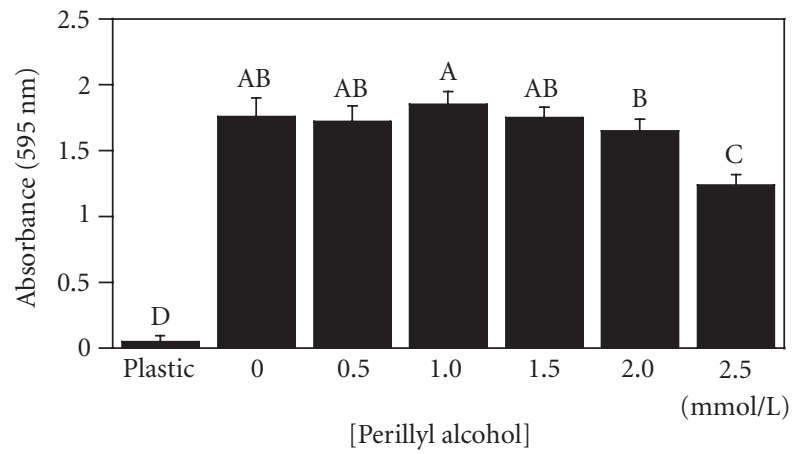

(a)

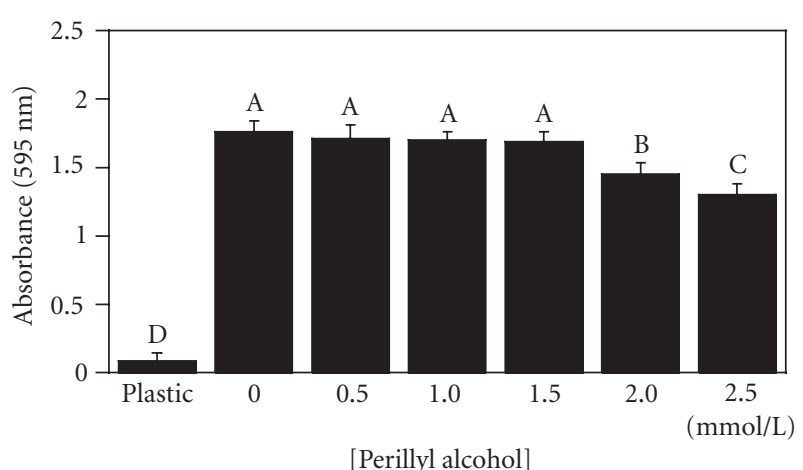

(b)

FIgURE 3. Perillyl alcohol ( $\leq 1.5 \mathrm{mmol} / \mathrm{L})$ does not interfere with breast cell adhesion to fibronectin. MCF-10A cells (a) or MDA-MB-435 cells (b) were plated on fibronectin for 30 minutes in the presence of the indicated concentrations of perillyl alcohol. Adherent cells were quantitated by staining with crystal violet, solubilizing adherent dye, and measuring absorbance at $595 \mathrm{~nm}$. Results expressed as mean \pm standard deviation $(n=8)$. A studentNuman-Keuls test identified in (a) two partly overlapping groups (letters A and B) and two independent groups (letters C and D); and in (b), four independent groups (letters A-D), $P \leq .05$. All groups are statistically different from one another (panel (a), ANOVA F: $[6,55]=144.88, P<.0001$; panel (b), ANOVA F: $[6,41]=252.45, P<.0001)$.

not as effective as $\mathrm{POH}$ in blocking cell proliferation in other cell types $[12,13]$.

Migration assays established that, a subtoxic dose $(0.5 \mathrm{mmol} / \mathrm{L})$ of $\mathrm{POH}$ inhibited haptotactic migration of MCF-10A cells on fibronectin (Figure 2). Again, this difference is most likely attributable to $\mathrm{POH}$, having a greater potency than limonene in the inhibition of small G-protein isoprenylation [13]. A probable mediator of this inhibited migration is the small G-protein RhoA, a member of the Rho family of small GTPases, that is involved in signaling a pathway for cell migration $[13,14]$.

To test the effect of $\mathrm{POH}$ on adhesion to fibronectin, both noncancerous (MCF-10A) cells and cancerous (MDAMB 435) cells were exposed for 18 hours to increasing concentrations of $\mathrm{POH}$ prior to a 30 -minute adhesion assay. Both MCF-10A and MDA-MB 435 cell lines tolerated up to $1.5 \mathrm{mmol} / \mathrm{L} \mathrm{POH}$ with no statistically significant variation 


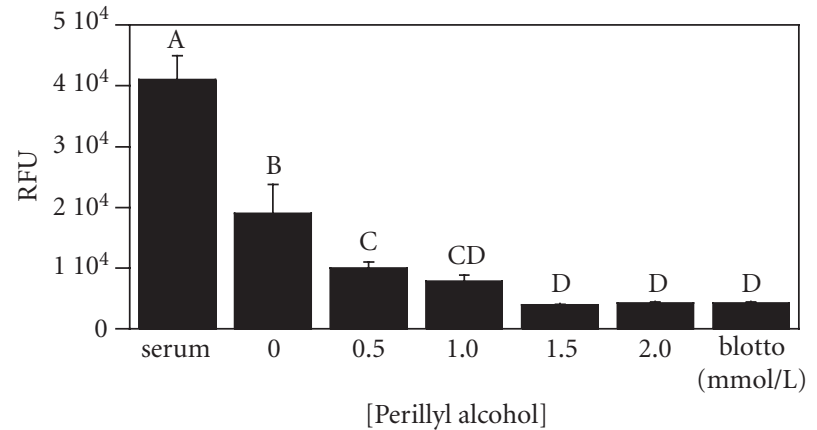

(a)

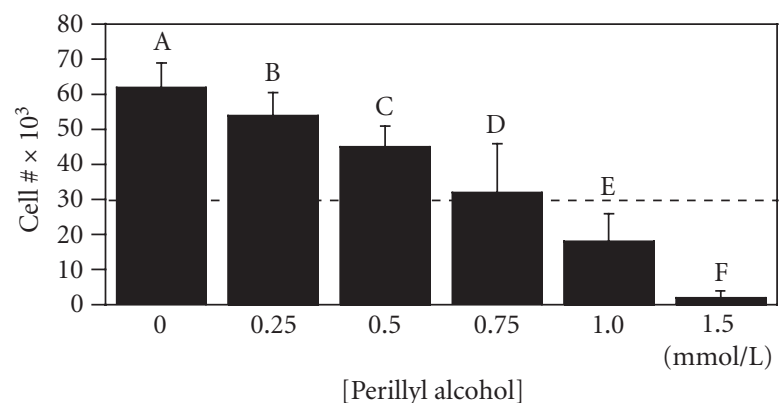

(b)

FIGURE 4. $0.5 \mathrm{mmol} / \mathrm{L}$ perillyl alcohol is a noncytotoxic inhibitor of MCF$10 \mathrm{~A}$ cell migration on fibronectin. Parallel measurements of cell migration (panel (a)) and cell growth (panel (b)) were performed as described for Figures 1 and 2 using MCF-10A cells exposed to the indicated concentrations of perillyl alcohol in a serum-free minimal medium. For panel A, a studentNuman-Keuls test identified four groups, two of which overlapped (letters A-D; $P \leq .05$ ). For panel (b), a student-Numan-Keuls test identified six groups (letters $\mathrm{A}-\mathrm{F} ; P \leq .05)$. All groups in each panel were statistically different from one another (panel (a), ANOVA F: $[6,20]=33.80, P<.0001$; panel (b), ANOVA F: $[7,79]=253.58, P<.0001)$.

compared to $0 \mathrm{mmol} / \mathrm{L}$ (Figure 3 ). The treated cells exhibited rounding and a loss of cytoskeletal organization, but remained viable as determined by Trypan Blue exclusion and MTT reduction assays (Wagner et al, unpublished data, 2000). These results, independently, confirm the low toxicity of $\mathrm{POH}$, and suggest that $\mathrm{POH}$ may inhibit the migration by disrupting the cytoskeletal machinery required to exert the necessary force for lamellar extension. Integrin mediated adhesion, however, remained unaffected.

To, directly, assess the dose response to $\mathrm{POH}$ treatment, growth and migration assays were performed in parallel for both cell lines. In MCF-10A cells, $0.5 \mathrm{mmol} / \mathrm{L} \mathrm{POH}$ inhibited the migration by over $75 \%$ and allowed the cell growth, although at a lower rate (Figure 4). In contrast, in MDAMB 435 cells, this dose inhibited the migration by over $85 \%$ but also reduced the cell number by nearly $20 \%$. In fact, all concentrations of $\mathrm{POH}$ that inhibited migration were cytotoxic in this cell line (Figure 5). This may be because this cell line expressing a higher level of RhoA, as has been reported in other tumor cells as compared to nontumorigenic cells [15]. An increased invasive phenotype is also characteristic

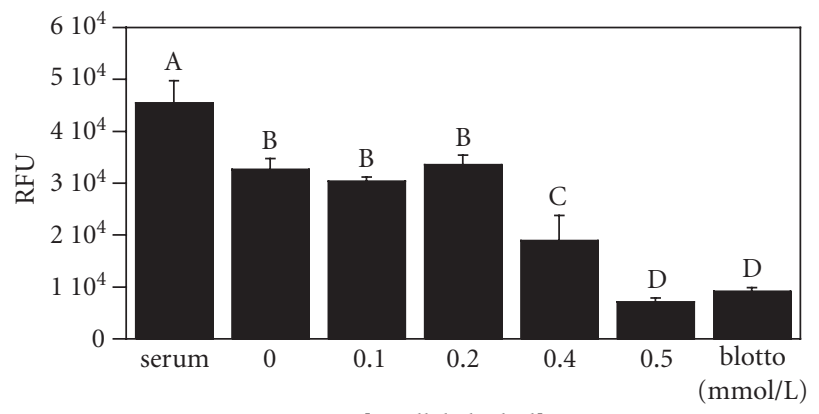

[Perillyl alcohol]

(a)

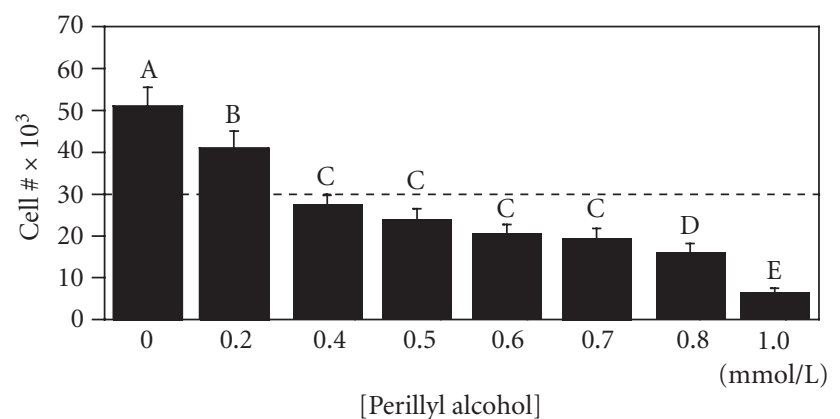

(b)

Figure 5. Perillyl alcohol is a cytotoxic inhibitor of MDA-MB-435 cell migration on fibronectin. Parallel measurements of cell migration (panel (a)) and cell growth (panel (b)) were performed as described for Figures 1 and 2 using MDA-MB-435 cells exposed to the indicated concentrations of perillyl alcohol in serum-free minimal medium. For panel (a), a student-NumanKeuls test identified four groups (letters A-D; $P \leq .05$ ). For panel (b), a student-Numan-Keuls test identified five groups (letters A-E; $P \leq .05$ ). All groups in each panel were statistically different from one another (panel (a), ANOVA F: $[6,23]=33.80, P<.0001$; panel (b), ANOVA F: $[7,80]=56.08$, $P<.0001)$.

of some liver and breast tumor cells in response to RhoA activation $[15,16]$. Additionally, $\mathrm{POH}$ treatment significantly increases apoptosis in pancreatic cancer cells relative to nonmalignant pancreas cells [17]. Thus, $\mathrm{POH}$ may exert its effects through separate mechanisms in MCF-10 and MDAMB 435 cells.

Given that a noncytotoxic dose of $\mathrm{POH}$ can inhibit the migration of noncancerous breast cells, and the same dose can kill cancerous breast cells, this suggests the possibility that $\mathrm{POH}$ may be used as a prophylactic treatment for patients at risk of developing breast cancer. Such a strategy is currently being used with the anti-estrogen drug, tamoxifen [18]. Further studies are under way in our laboratory to explore the effects of low doses of $\mathrm{POH}$ on tumor progression.

\section{ACKNOWLEDGMENTS}

We wish to thank J. Steven de Belle for assistance with statistical analysis. This work was supported by a career development grant DAMD17-98-1-8325 to GEP from the United States Army Breast Cancer Research Program. 


\section{REFERENCES}

[1] Alison M, Sarraf C. Understanding Cancer. London: Cambridge University Press; 1997.

[2] Liotta LA. Tumor invasion and metastases-role of the extracellular matrix: Rhoads memorial award lecture. Cancer Res. 1986;46(1):1-7.

[3] Kohn EC, Liotta LA. Molecular insights into cancer invasion: strategies for prevention and intervention. Cancer Res. 1995;55(9):1856-1862.

[4] Rust WL, Huff JL, Plopper GE. Screening assay for promigratory/antimigratory compounds. Anal Biochem. 2000;280(1):11-19.

[5] Crowell PL, Gould MN. Chemoprevention and therapy of cancer by d-limonene. Crit Rev Oncog. 1994;5(1):122.

[6] Crowell PL. Prevention and therapy of cancer by dietary monoterpenes. J Nutr. 1999;129(3):775S-778S.

[7] Vigushin DM, Poon GK, Boddy A, et al. Phase I and pharmacokinetic study of d-limonene in patients with advanced cancer. Cancer Chemother Pharmacol. 1998;42(2):111-117.

[8] Phillips LR, Malspeis L, Supko JG. Pharmacokinetics of active drug metabolites after oral administration of perillyl alcohol, an investigational antineoplastic agent, to the dog. Drug Metab Dispos. 1995;23(7):676-680.

[9] Ren Z, Elson CE, Gould MN. Inhibition of type I and type II geranylgeranyl-protein transferases by the monoterpene perillyl alcohol in NIH3T3 cells. Biochem Pharmacol. 1997;54(1):113-120.

[10] Clark SS, Perman SM, Sahin MB, Jenkins GJ, Elegbede JA. Antileukemia activity of perillyl alcohol (POH): uncoupling apoptosis from G0/G1 arrest suggests that the primary effect of $\mathrm{POH}$ on Bcr/Abl-transformed cells is to induce growth arrest. Leukemia. 2002;16(2):213-222.

[11] Plopper GE, Domanico SZ, Cirulli V, Kiosses WB, Quaranta V. Migration of breast epithelial cells on Laminin-5: differential role of integrins in normal and transformed cell types. Breast Cancer Res Treat. 1998;51(1):57-69.

[12] Gelb MH, Tamanoi F, Yokoyama K, Ghomashchi F, Esson K, Gould MN. The inhibition of protein prenyltransferases by oxygenated metabolites of limonene and perillyl alcohol. Cancer Lett. 1995;91(2):169-175.

[13] Crowell PL, Ren Z, Lin S, Vedejs E, Gould MN. Structure-activity relationships among monoterpene inhibitors of protein isoprenylation and cell proliferation. Biochem Pharmacol. 1994;47(8):1405-1415.

[14] Kjoller L, Hall A. Signaling to Rho GTPases. Exp Cell Res. 1999;253(1):166-179.

[15] Yoshioka K, Nakamori S, Itoh K. Overexpression of small GTP-binding protein RhoA promotes invasion of tumor cells. Cancer Res. 1999;59(8):2004-2010.

[16] Bourguignon LY, Zhu H, Shao L, Zhu D, Chen YW. Rho-kinase (ROK) promotes CD44v(3,8-10)ankyrin interaction and tumor cell migration in metastatic breast cancer cells. Cell Motil Cytoskeleton. 1999;43(4):269-287.
[17] Stayrook KR, McKinzie JH, Burke YD, Burke YA, Crowell PL. Induction of the apoptosis-promoting protein Bak by perillyl alcohol in pancreatic ductal adenocarcinoma relative to untransformed ductal epithelial cells. Carcinogenesis. 1997;18(8):1655-1658.

[18] Duffy SW, Nixon RM. Estimates of the likely prophylactic effect of tamoxifen in women with high risk BRCA1 and BRCA2 mutations. Br J Cancer. 2002;86(2):218221.

* Corresponding author.

E-mail: ploppg@rpi .edu

Fax: +1 518276 2162; Tel: +1 5182768288 

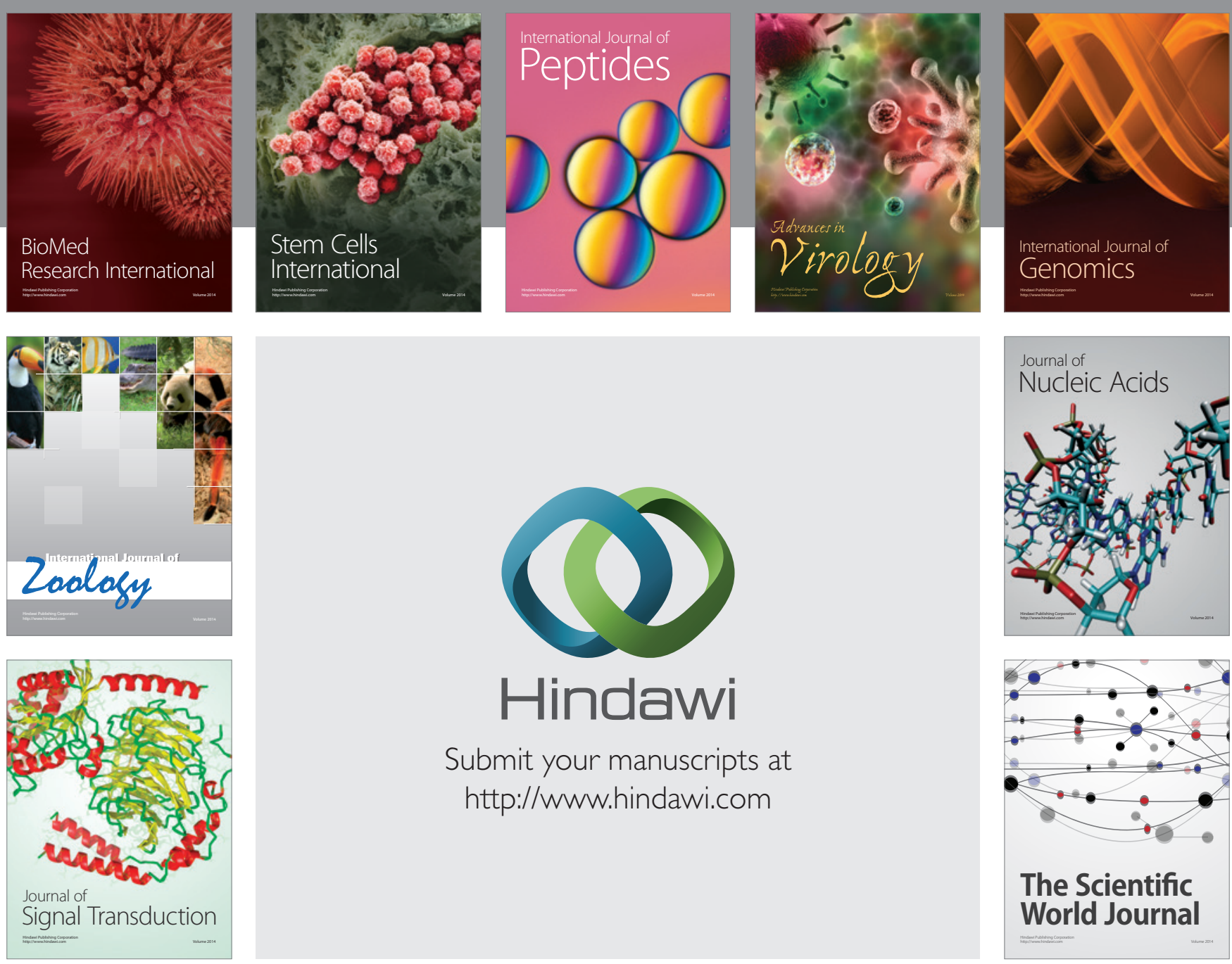

Submit your manuscripts at

http://www.hindawi.com
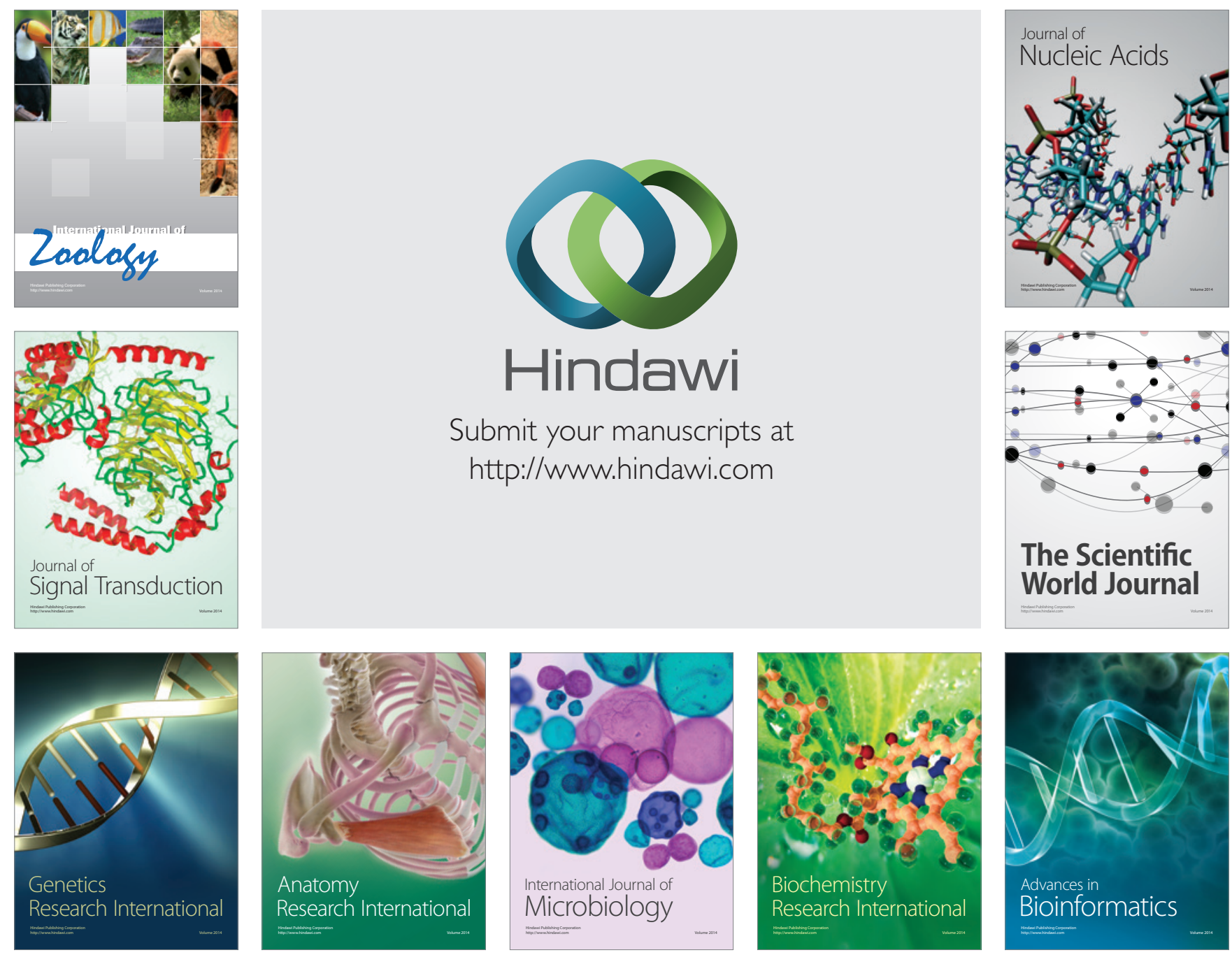

The Scientific World Journal
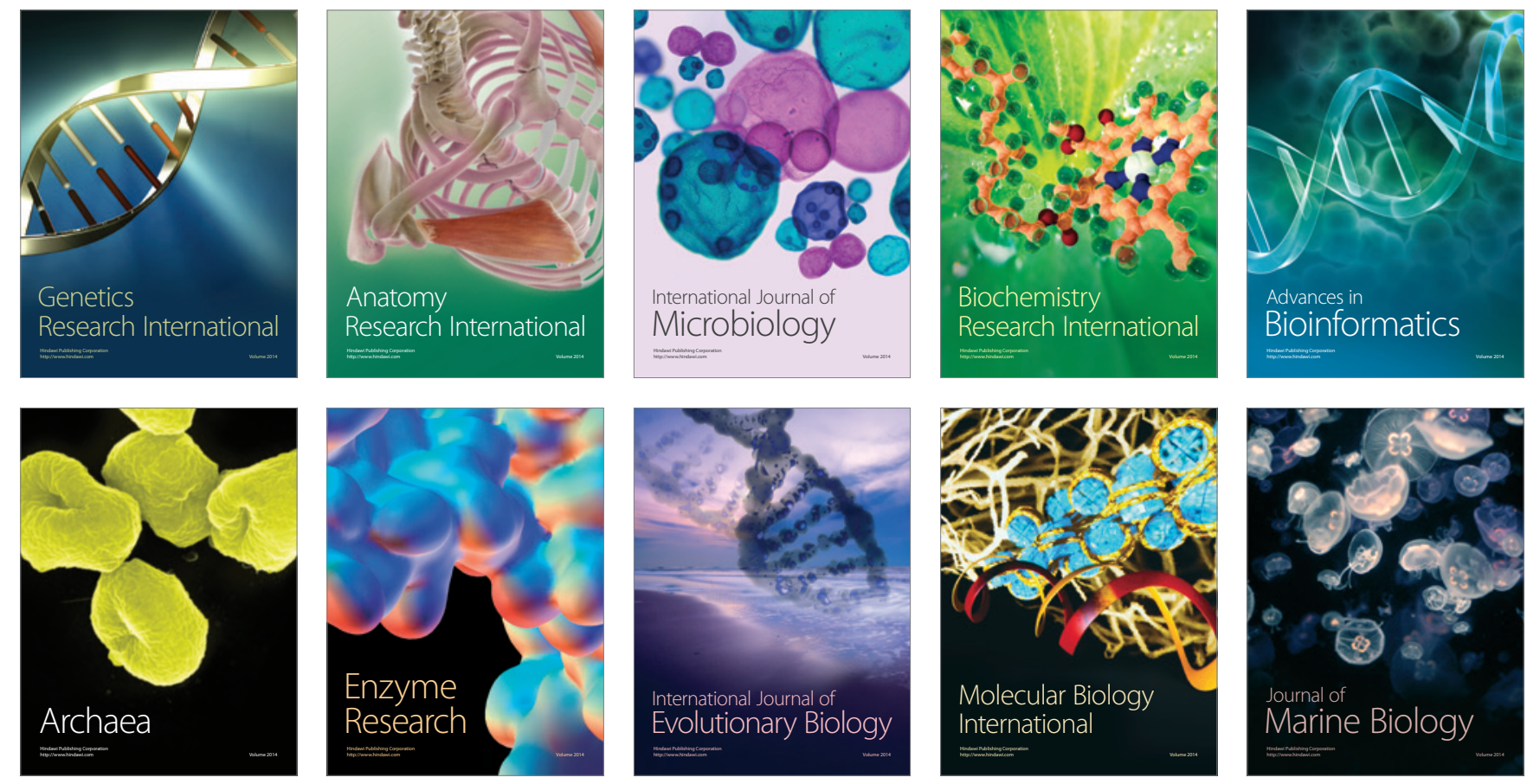